\title{
FOSSILIZED BIOMATS AS THE POSSIBLE SOURCE OF HIGH NATURAL RADIONUCLIDE CONTENT AT THE JURASSIC ÚRKÚT MANGANESE ORE DEPOSIT, HUNGARY
}

\section{Ildikó GYOLLAI ${ }^{1}$, Márta POLGÁRI ${ }^{1,2 *}$, Lóránt BÍRÓ ${ }^{1}$, Tamás VIGH ${ }^{3}$, Tibor KOVÁCS ${ }^{4}$ \& Elemér PÁL-MOLNÁR ${ }^{5}$}

${ }^{1}$ Research Centre for Astronomy and Geosciences, Geobiomineralization and Astrobiological Research Group, Institute for Geological and Geochemical Research, Hungarian Academy of Sciences, 1112 Budapest, Budaörsi str. 45, Hungary, e-mail: rodokrozit@gmail.com,gyildi@gmail.com

${ }^{2}$ Eszterházy Károly University, Department of Natural Geography and Geoinformatics, 3300 Eger, Leányka str. 6/C, Hungary

${ }^{3}$ Mangán Ltd, Úrkút, Külterület 1.8409 Hungary, e-mail: drvightamas@gmail.com

${ }^{4}$ Institute of Radiochemistry and Radioecology, University of Pannonia, Egyetem str. 10, Veszprém, H-8200, Hungary, Phone: +3688 624-789, Fax: +3688624-178, e-mail: kt@almos.uni-pannon.hu

${ }^{5}$ Szeged University, Department of Mineralogy, Geochemistry and Petrology 'Vulcano' Petrology and Geochemistry Research Group, 6722 Szeged, Egyetem str. 2, Hungary, e-mail: palm@geo.u-szeged.hu, *corresponding author

\begin{abstract}
The ${ }^{220} \mathrm{Rn}$ and ${ }^{222} \mathrm{Rn}$ concentration in the Úrkút Manganese Formation is anomalously high, and it causes health risk for the attendants of the Úrkút Manganese Mine. In this study we suggest a new model for the high ratio of different natural radionuclides by the new genetic model of the Úrkút Manganese Formation. Fossilized Fe-rich biomats were found in the whole section of the deposit. Based on these, the formation of different types of Mn-ores by one or two step microbial mediation can be assumed. The biomats represent large amounts of organic matter offering large surfaces with negative ligands, as well as poorly ordered mineral phases like ferrihydrite and clay minerals with large and reactive surfaces. These features offer high capability of cation binding, among them ions of radioactive elements, which could be fixed on the active or inactive organic matter, as well as on mineral surfaces. The decay of fixed nuclides could result high ${ }^{220} \mathrm{Rn}$ and ${ }^{222} \mathrm{Rn}$ concentration in the Úrkút Mine.
\end{abstract}

Keywords: biomats, black shale, geomicrobiology, radon, natural radionuclide

\section{INTRODUCTION}

\subsection{Biomats}

Biomats are the common appearance of local microbial communities, with diverse species and strains on different surfaces. The biomats are widespread from the guts of the animals to deep sea hydrothermal springs. In this paper, we discuss biomats as geobiological features, in the form of thin films and layers on the rock surfaces with variable thickness (from $\mathrm{cm}$ to $\mathrm{m}$ ), which are built up by organic and inorganic matters. These biomats can selectively enrich ions, among them ions of radioactive elements. In a section the biomats show fine laminae, which differ in their colors, textures and elemental contents (Fig. 1). The different laminae may indicate different species or strains with different metabolic activity, and some evolutionary change could be observable in the vertical (or sometimes horizontal) zonation as well. If the structure of the biomat is complex and there is available sunlight, the uppermost layer is enriched with cyanobacteria which are phototrophs, and the lowermost parts by methanotrophs as the chemical gradient decrease. Between these two layers, different chemotroph species live, and these species have complex ecological connection with each other from competition to cooperation (Krumbein et al., 2003; Konhasuer, 2007).

The appearance of the biomat could indicate the enrichment of some elements, usually they are 

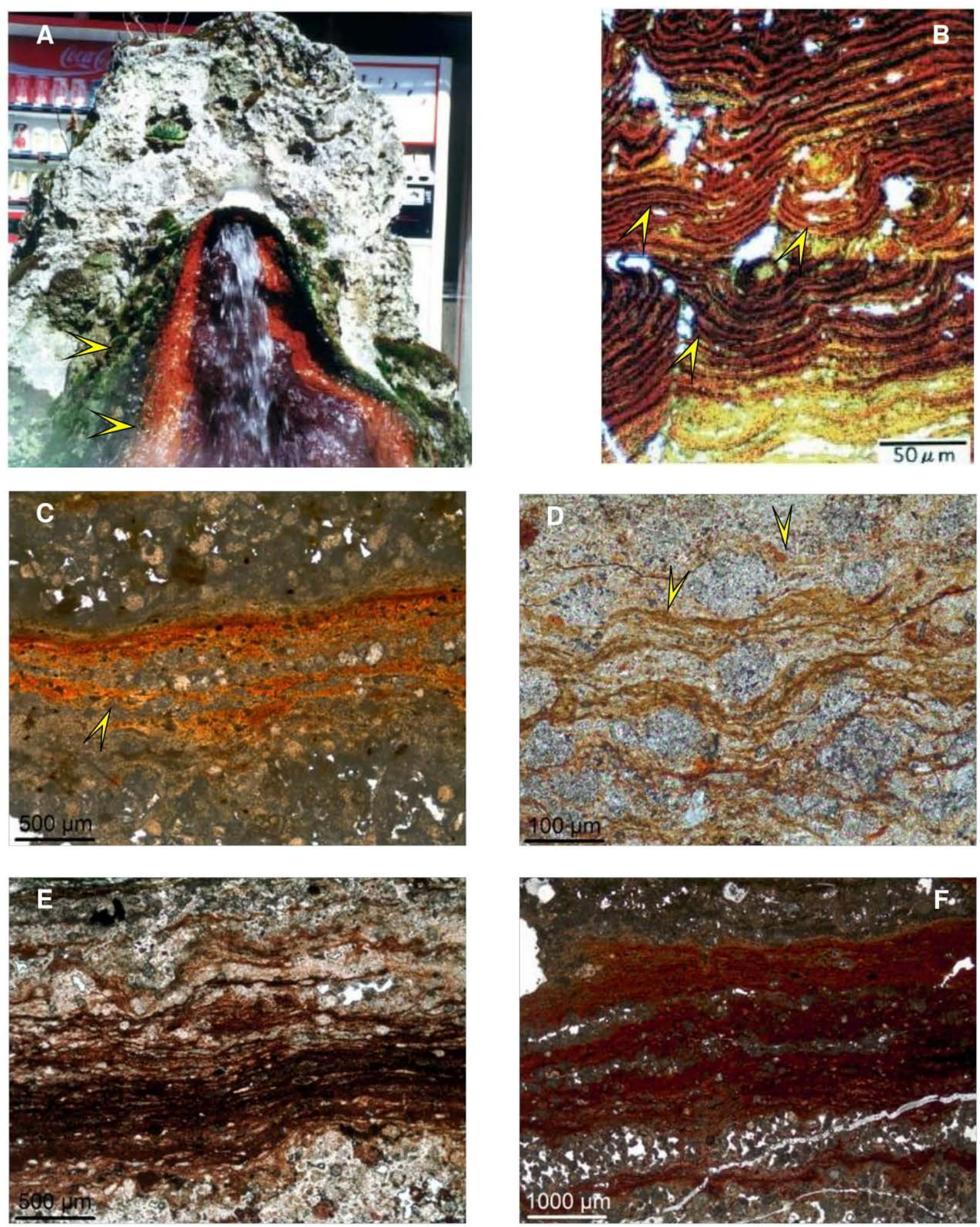

Figure 1. Biomats. (A) Recent biomat in a hot spring - the different color of the mat shows different metabolism (arrows, Hirayu, Japan); (B) Optical light micrograph of a fine laminated recent Fe-, Mn-rich biomat from Akayu hot spring (arrows, Iwo Jima, Japan) (Tazaki, 1999); (C-F) Fe-rich biomats (arrows) in quartz matrix in geysirite, Miocene age (15 My), Mátra Mts., Hungary (Photos by A. Müller)

formed on geochemical borders where the chemical gradient shows great change on a very small distance, like hot springs or estuarines.

The physical structure of the biomats is porous, web- or sponge-like, and water can stream through freely. The chemical compounds of the biomats are the organic matter (lipids, steranes, enzymes, proteins, etc.) with mainly soluble inorganic content which are usually derived from cellular activity or from the bedrock (Konhauser, 2007). 
By the metabolic activity of the microbes, different minerals could form from the soluble inorganic components. The elemental content of the minerals usually reflects the microbial metabolic preferences, but the first mineral phases which come out are usually poorly ordered with a high reactive surface (e.g. ferrihydrite, vernadite, clay minerals, etc.). These minerals could adsorb different atoms or ions, whether they are radiogenic or not, based on this feature, this mineral can act as a sorbent and retard migration in polluted environments.

Another process for cation retention is the high cation capacity of different types of the organic matter. Usually cell walls are encrusted by different molecules such as proteins or enzymes, which have multiple molecular structure and functional groups, but usually have some ligands with negative charge (e.g. $(\mathrm{OH})^{-}$groups). These ligands could form binds with $\mathrm{Ca}^{2+}, \mathrm{Fe}^{2+}, \mathrm{K}^{+}$etc. cations, favoring mineral nucleation.

In special environments and results of the metabolic processes the biomats can be fossilized, in this occasion we can observe the fine laminae shown by different minerals and textures with the cyclicity of special organic matter (e.g. hopanes) (Wiener et al., 2003; Konhauser, 2007).

Ions of radioactive elements (e.g. Ra, U, Th, etc. and their decay daughter elements) can be enriched in biomats via an active or a passive way inside a very small area (a few $\mathrm{m}^{2}$ ). As the isotopes decay, the area has anomalously high gamma ray, or radon content. Recently we have some reports about this phenomena (for details see Tsezos et al., 1987; Fujisawa \& Tazaki, 2003; Tazaki, 2009; etc.), it usually appears in hot springs, where high natural radionuclide content of the water derived by the leaching of lower rocks. But we have less information about the formation and the pursuit of these kinds of biomats.

\subsection{The Toarcian Úrkút Manganese Ore Deposit}

The black shale-hosted Early-Jurassic (196 My) Úrkút Manganese Formation (ÚMF) is located at the central part of the Transdanubian Range (TR) (Fig. 2A) with a huge mass of economically important Mn ore (approx. $86 \mathrm{Mt}$ metal content), which was embedded in Mesozoic limemarlstone (Fig. 2B). The ore deposit is built up by two main mineral phases (Mn oxide and carbonate minerals). The underground exploitation has occurred over a hundred years and ended in 2017 (Polgári et al., 2017).

The mineralogical and geochemical properties of the Mn ore deposit are characterized by Polgári et al. (2012a) providing a new genetic model. They assume that the ore formed by a two-step microbial activity. Firstly, chemolithoautotrophic organisms oxidized the soluble metal cations $\left(\mathrm{Mn}^{2+}, \mathrm{Fe}^{2+}\right.$ etc.) into insoluble, poorly ordered mineral forms (manganite, vernadite, pyrolusite, cryptomelane, etc.) under oxic environmental conditions, where the source of the metal elements could have been a diffuse discharge hydrothermal activity (synsediment phase, sequestration of metals into the sediment as proto ore). Secondly, heterotrophic microbes could reduce the Mnand Fe-oxide minerals to carbonate form (mainly rhodochrosite, as main ore mineral), via oxidizing the organic matter and mineralizing it in the form of carbonates during the early diagenetic processes under suboxic-anoxic environmental conditions (diagenetic phase).

Former studies show that the main primordial terrestrial isotopes (e.g. ${ }^{238} \mathrm{U}$; ${ }^{232} \mathrm{Th} ;{ }^{40} \mathrm{~K}$ ) occur in manganese minerals in trace amounts (Grasselly \& Pantó, 1988; Abel-Ghany, 2010). As Kávási et al. (2007, 2009) points out, in the caverns of the Úrkút Manganese Mine are high concentrations of Rn gas, the average ${ }^{222} \mathrm{Rn}$ values are $600 \mathrm{~Bq} / \mathrm{m}^{-3}$ (without ventilation it reaches $2000-3000 \mathrm{~Bq} / \mathrm{m}^{-3}$, and in caverns $10,000 \mathrm{~Bq} / \mathrm{m}^{-3}$ also occurred). The average ${ }^{220} \mathrm{Rn}$ (thoron gas) values are $200-300 \mathrm{~Bq} / \mathrm{m}^{-3}$ (without ventilation it reaches $1000 \mathrm{~Bq} / \mathrm{m}^{-3}$ ). Vigh et al. (2013) discussed the enrichment of natural radionuclides and $\mathrm{Rn}$ in the different parts of the ore, while the $\mathrm{K}$ enriched in the green, celadonite-bearing $\mathrm{Mn}$ carbonate ore (average $2.29 \mathrm{wt}$. \%), the $\mathrm{U}$ and $\mathrm{Th}$ enriched in the clay mineral rich black shale zones (1.9 and $8.4 \mathrm{ppm}$, respectively). It was shown that the geochemical behaviour of the parent and daughter isotopes is different. Comparing the rock types and the average activity concentrations of ${ }^{232} \mathrm{Th},{ }^{234} \mathrm{Th}$ and ${ }^{226} \mathrm{Ra}$, there were ore horizons where parent favoured disequilibrium in U-series was detected, while at other horizons $\mathrm{U}$ has leached out leaving behind radium from which radon is produced (Vigh et al., 2013).

Previous interpretation summarized by Vigh et al. (2013) proposed the following aspects in the background of elevated radon concentration: (i) contribution of $\mathrm{C}_{\text {org }}$ in the formation of black shale and Mn-carbonate ore; (ii) P-rich layers represented by fish remnants in heterogenous distribution; (iii) clay-rich composition of the ore deposit (celadonite occurring in $\mathrm{Mn}$ carbonate ore, containing $\mathrm{K}$ ), moreover, the adsorption characteristics of clay minerals should also be taken into account concerning the binding of natural radionuclides; (iv) the microbial mediation in formation processes of manganese mineralization, and the marinegeochemical relationship of $\mathrm{U}$ also preferred in microbial processes; (v) the effect of secondary 

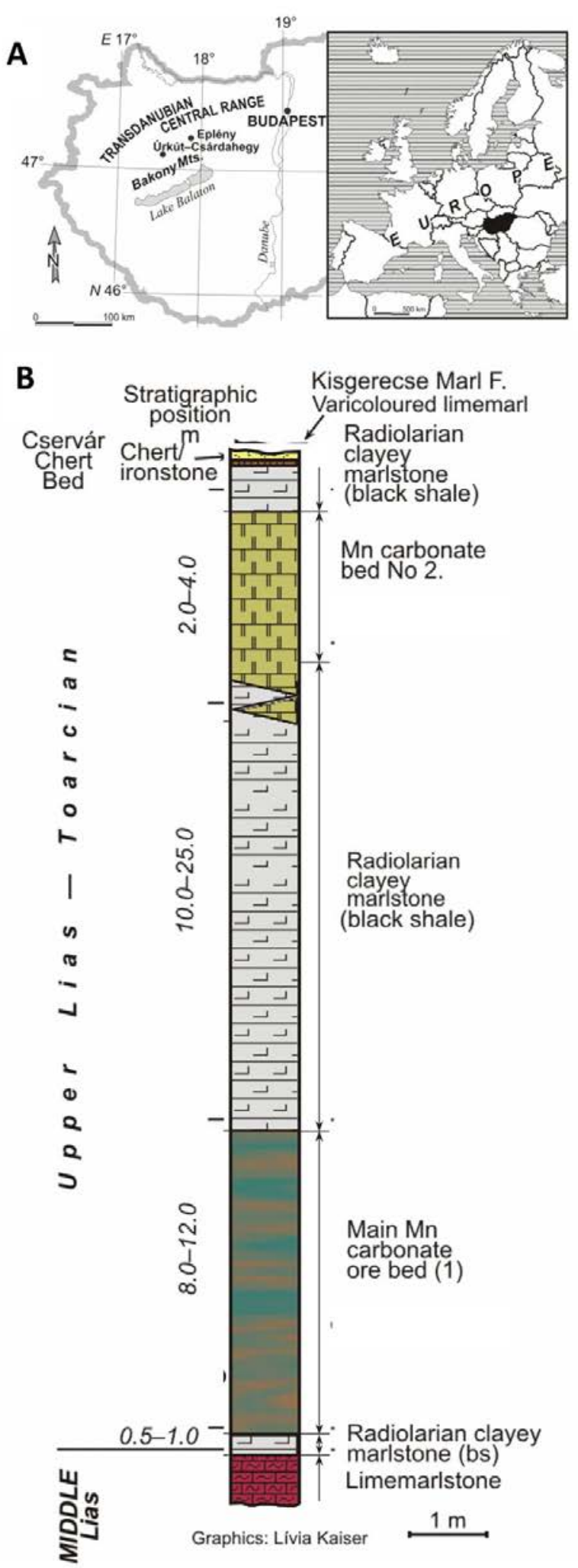

Figure 2. Locality of the Úrkút Manganese Formation (GPS coordinates: N 4705’03.3’’; E 17³8’30.6’’) (A) and the geological cross-section of the deposit (B)

oxidizing processes causing chemical transformations; (vi) in spite of the low U content of the deposit, high radon concentration occurs during underground exploitation, as huge mass of the ore (ore types and black shale) is in contact with mine air representing the source of geo hazard.

As the contribution of biomat formation in the selective enrichment of natural radionuclides was not taken into consideration, so the aim of this paper is to provide evidences of this scenario, providing new data and also reviewing earlier considerations.

\section{MATERIALS AND METHODS}

The measurements were carried out on 54 samples collected from the different types of the initial (Mn oxide rich) part and the main carbonate ore bed of the deposit; 3 from the limemarlstone footwall, 6 from the oxide ore parts, 5 from the clay mineral-rich and 40 from the carbonate-rich ore zones (Table 1, Fig. 2B). Polished samples and thin sections were made for microtextural and micromineralogical studies.

An ECLIPSE 600 optical rock microscope was used (IGGR, HAS, Budapest, Hungary) for the microtextural and basic mineralogical examinations.

Based on these, the mineralogical and organic matter content was characterized by a Bruker VERTEX 70 Fourier transform infrared spectrometer (FTIR) equipped with a Bruker HYPERION 2000 microscope with a 20x ATR objective and MCT-A detector. During ATR analysis, the samples were contacted with a Ge crystal ( 0.5 micron) tip on the selected $1 \mathrm{~N}$ pressure. The measurement was conducted for 32 seconds in the 600 $4000 \mathrm{~cm}^{-1}$ range with $4 \mathrm{~cm}^{-1}$ resolution. Opus 5.5 software was used to evaluate the data. For Mn oxide determination the equipment could not be used, as those peaks occur in the $<600 \mathrm{~cm}^{-1}$ range.

All of the examinations were made on standard thin sections (7), and 21 spectra were acquired. During the FTIR investigations some types of organic matter (carbon-carbon bonds, carbon-hydrogen bonds, etc.) were characterized. Contamination of epoxy glue and glass were taken into consideration, and peaks of these phases were not considered.

Detailed high resolution petrological, mineralogical, geochemical (main and trace element, stable $\mathrm{C}, \mathrm{O}, \mathrm{S}$ isotope composition) and organic geochemical measurements and interpretation of a large sample set was also taken into consideration (Polgári et al., 2012ab, 2013, 2016ab).

\section{RESULTS AND DISCUSSION}

Based on the optical rock microscopy we assumed that the Mn oxide and carbonate ore have very heterogenous mineralogical content with typical textural elements. In the initial Mn ore as well as in the main Mn carbonate ore bed and the host black 
Table 1. List of samples and used methods (Úrkút Mine, Shaft No. III, western minefield, deep level, +180 and +186 mBf)

\begin{tabular}{|c|c|c|c|c|c|c|c|c|c|c|c|}
\hline No. & Samples & rock type & Ore zone & \multicolumn{7}{|c|}{ Methods } & References \\
\hline & ID & & & A & B* & $\mathrm{C}^{*}$ & D* & $\mathbf{E}^{*}$ & $\mathbf{F}$ & G* & \\
\hline 1 & $2 / 4 / A$ & $\begin{array}{c}\text { footwall } \\
\text { limemarlstone }\end{array}$ & footwall & $\mathrm{X}$ & & & & & & & $\begin{array}{l}\text { Molnár et al., } \\
\text { (2017) }\end{array}$ \\
\hline 2 & $2 / 4 / B$ & $\begin{array}{c}\text { footwall } \\
\text { limemarlstone }\end{array}$ & footwall & $\mathrm{X}$ & & & & & & & $\downarrow$ \\
\hline 3 & $2 / 4 / D$ & $\begin{array}{c}\text { footwall } \\
\text { limemarlstone }\end{array}$ & footwall & $\mathrm{X}$ & & & & & & & \\
\hline 4 & $1 / 1 / A$ & $\begin{array}{l}\text { initial Fe-Mn } \\
\text { oxide }\end{array}$ & footwall & $\mathrm{X}$ & $\mathrm{X}$ & & $\mathrm{X}$ & & $\mathrm{O}$ & & \\
\hline 5 & $1 / 1 / B$ & $\begin{array}{l}\text { initial Fe-Mn } \\
\text { oxide }\end{array}$ & footwall & $\mathrm{X}$ & $\mathrm{X}$ & & $\mathrm{X}$ & & $\mathrm{O}$ & & \\
\hline 6 & $1 / 1 / C$ & $\begin{array}{l}\text { initial Fe-Mn } \\
\text { oxide }\end{array}$ & footwall & $\mathrm{X}$ & $\mathrm{X}$ & & $\mathrm{X}$ & $\mathrm{X}$ & $\mathrm{O}$ & & \\
\hline 7 & $1 / 1 / D$ & $\begin{array}{l}\text { initial Fe-Mn } \\
\text { oxide }\end{array}$ & footwall & $\mathrm{X}$ & $\mathrm{X}$ & & $\mathrm{X}$ & $\mathrm{X}$ & $\mathrm{O}$ & $\mathrm{X}$ & \\
\hline 8 & $2 / 1 / A$ & $\begin{array}{l}\text { initial Fe-Mn } \\
\text { oxide }\end{array}$ & footwall & $\mathrm{X}$ & $\mathrm{X}$ & & $\mathrm{X}$ & $\mathrm{X}$ & $\mathrm{O}$ & & \\
\hline 9 & $2 / 1 / B$ & $\begin{array}{c}\text { initial Fe-Mn } \\
\text { oxide }\end{array}$ & footwall & $\mathrm{X}$ & $\mathrm{X}$ & & $\mathrm{X}$ & $\mathrm{X}$ & $\mathrm{O}$ & & \\
\hline 10 & 2/2/A & $\begin{array}{c}\text { clay mineral-rich } \\
\text { footwall }\end{array}$ & footwall & $\mathrm{X}$ & $\mathrm{X}$ & & $\mathrm{X}$ & & & $\mathrm{X}$ & \\
\hline 11 & $2 / 2 / B$ & $\begin{array}{l}\text { clay mineral-rich } \\
\text { footwall }\end{array}$ & footwall & $\mathrm{X}$ & $\mathrm{X}$ & & $\mathrm{X}$ & & & $\mathrm{X}$ & \\
\hline 12 & $2 / 3 / A$ & $\begin{array}{l}\text { clay mineral-rich } \\
\text { footwall }\end{array}$ & footwall & $\mathrm{X}$ & $\mathrm{X}$ & & $\mathrm{X}$ & & & & \\
\hline 13 & $2 / 4 / C$ & $\begin{array}{l}\text { clay mineral-rich } \\
\text { footwall }\end{array}$ & footwall & $\mathrm{X}$ & $\mathrm{X}$ & & & $\mathrm{X}$ & $\mathrm{O}$ & & \\
\hline 14 & $2 / 4 / E$ & $\begin{array}{l}\text { clay mineral-rich } \\
\text { footwall }\end{array}$ & footwall & $\mathrm{X}$ & $\mathrm{X}$ & & & & & & \\
\hline 15 & $1 / 12$ & $\begin{array}{c}\text { Radiolarian } \\
\text { clayey marlstone }\end{array}$ & $\begin{array}{l}\text { radiolarian clayey } \\
\text { marlstone (Bs1) }\end{array}$ & $\mathrm{X}$ & $\mathrm{X}$ & & $\mathrm{X}$ & & & $\mathrm{X}$ & $\begin{array}{l}\text { Polgári et al. } \\
\text { (2012a) }\end{array}$ \\
\hline 16 & $1 / 13$ & green type ore & $\begin{array}{l}\text { main Mn carbonate } \\
\text { ore bed }\end{array}$ & $\mathrm{X}$ & $\mathrm{X}$ & & $\mathrm{X}$ & & & $\mathrm{X}$ & $\begin{array}{l}\text { Polgári et al., } \\
\text { (2012ab, 2013) }\end{array}$ \\
\hline 17 & $1 / 14$ & green type ore & $\begin{array}{c}\text { main Mn carbonate } \\
\text { ore bed }\end{array}$ & $\mathrm{X}$ & $\mathrm{X}$ & & $\mathrm{X}$ & & & $\mathrm{X}$ & $\downarrow$ \\
\hline 18 & $1 / 15$ & green type ore & $\begin{array}{c}\text { main Mn carbonate } \\
\text { ore bed }\end{array}$ & $\mathrm{X}$ & $\mathrm{X}$ & & $\mathrm{X}$ & & & $\mathrm{X}$ & \\
\hline 19 & $1 / 16$ & green type ore & $\begin{array}{c}\text { main Mn carbonate } \\
\text { ore bed }\end{array}$ & $\mathrm{X}$ & $\mathrm{X}$ & & $\mathrm{X}$ & & & $\mathrm{X}$ & \\
\hline 20 & $1 / 17$ & green type ore & $\begin{array}{c}\text { main Mn carbonate } \\
\text { ore bed }\end{array}$ & $\mathrm{X}$ & $\mathrm{X}$ & & $\mathrm{X}$ & & & $\mathrm{X}$ & \\
\hline 21 & $3 / 7$ & brown ore type & $\begin{array}{c}\text { main Mn carbonate } \\
\text { ore bed }\end{array}$ & $\mathrm{X}$ & $\mathrm{X}$ & & $\mathrm{X}$ & & & $\mathrm{X}$ & \\
\hline 22 & $3 / 8$ & brown ore type & $\begin{array}{c}\text { main Mn carbonate } \\
\text { ore bed }\end{array}$ & $\mathrm{X}$ & $\mathrm{X}$ & & $\mathrm{X}$ & & & $\mathrm{X}$ & \\
\hline 23 & $3 / 9$ & brown ore type & $\begin{array}{c}\text { main Mn carbonate } \\
\text { ore bed }\end{array}$ & $\mathrm{X}$ & $\mathrm{X}$ & & $\mathrm{X}$ & & & $\mathrm{X}$ & \\
\hline 24 & $3 / 13$ & brown ore type & $\begin{array}{c}\text { main Mn carbonate } \\
\text { ore bed }\end{array}$ & $\mathrm{X}$ & $\mathrm{X}$ & & $\mathrm{X}$ & & & $\mathrm{X}$ & \\
\hline 25 & $3 / 14$ & brown ore type & $\begin{array}{c}\text { main Mn carbonate } \\
\text { ore bed }\end{array}$ & $\mathrm{X}$ & $\mathrm{X}$ & & $\mathrm{X}$ & & & $\mathrm{X}$ & \\
\hline 26 & $4 / 4$ & brown ore type & $\begin{array}{c}\text { main Mn carbonate } \\
\text { ore bed }\end{array}$ & $\mathrm{X}$ & $\mathrm{X}$ & & $\mathrm{X}$ & & & $\mathrm{X}$ & \\
\hline 27 & $4 / 7$ & brown ore type & $\begin{array}{c}\text { main Mn carbonate } \\
\text { ore bed }\end{array}$ & $\mathrm{X}$ & $\mathrm{X}$ & & $\mathrm{X}$ & & & $\mathrm{X}$ & \\
\hline
\end{tabular}




\begin{tabular}{|c|c|c|c|c|c|c|c|c|}
\hline No. & Samples & rock type & Ore zone & \multicolumn{4}{|c|}{ Methods } & References \\
\hline 28 & $4 / 8$ & brown ore type & $\begin{array}{c}\text { main Mn carbonate } \\
\text { ore bed }\end{array}$ & $\mathrm{X}$ & $\mathrm{X}$ & $\mathrm{X}$ & $\mathrm{X}$ & \\
\hline 29 & $4 / 9$ & brown ore type & $\begin{array}{c}\text { main Mn carbonate } \\
\text { ore bed }\end{array}$ & $\mathrm{X}$ & $\mathrm{X}$ & $\mathrm{X}$ & $\mathrm{X}$ & \\
\hline 30 & $4 / 10$ & brown ore type & $\begin{array}{c}\text { main Mn carbonate } \\
\text { ore bed }\end{array}$ & $\mathrm{X}$ & $\mathrm{X}$ & $\mathrm{X}$ & $\mathrm{X}$ & \\
\hline 31 & $4 / 12$ & brown ore type & $\begin{array}{l}\text { main Mn carbonate } \\
\text { ore bed }\end{array}$ & $\mathrm{X}$ & $\mathrm{X}$ & $\mathrm{X}$ & $X$ & \\
\hline 32 & $4 / 13$ & brown ore type & $\begin{array}{c}\text { main Mn carbonate } \\
\text { ore bed }\end{array}$ & $\mathrm{X}$ & $\mathrm{X}$ & $\mathrm{X}$ & $X$ & \\
\hline 33 & $4 / 15$ & green type ore & $\begin{array}{c}\text { main Mn carbonate } \\
\text { ore bed }\end{array}$ & $X$ & $X$ & $\mathrm{X}$ & $X$ & \\
\hline 34 & $4 / 16$ & green type ore & $\begin{array}{c}\text { main Mn carbonate } \\
\text { ore bed }\end{array}$ & $\mathrm{X}$ & $\mathrm{X}$ & $\mathrm{X}$ & $X$ & \\
\hline 35 & $4 / 17$ & green type ore & $\begin{array}{c}\text { main Mn carbonate } \\
\text { ore bed }\end{array}$ & $X$ & $\mathrm{X}$ & $\mathrm{X}$ & $X$ & \\
\hline 36 & $4 / 19$ & green type ore & $\begin{array}{l}\text { main Mn carbonate } \\
\text { ore bed }\end{array}$ & $\mathrm{X}$ & $\mathrm{X}$ & $\mathrm{X}$ & $\mathrm{X}$ & \\
\hline 37 & $4 / 20$ & green type ore & $\begin{array}{c}\text { main Mn carbonate } \\
\text { ore bed }\end{array}$ & $\mathrm{X}$ & $\mathrm{X}$ & $\mathrm{X}$ & $\mathrm{X}$ & \\
\hline 38 & $4 / 23$ & green type ore & $\begin{array}{c}\text { main Mn carbonate } \\
\text { ore bed }\end{array}$ & $\mathrm{X}$ & $\mathrm{X}$ & $\mathrm{X}$ & $\mathrm{X}$ & \\
\hline 39 & $4 / 25$ & brown ore type & $\begin{array}{c}\text { main Mn carbonate } \\
\text { ore bed }\end{array}$ & $\mathrm{X}$ & $\mathrm{X}$ & $\mathrm{X}$ & $\mathrm{X}$ & \\
\hline 40 & $5 / 1$ & gray ore type & $\begin{array}{c}\text { main Mn carbonate } \\
\text { ore bed }\end{array}$ & $\mathrm{X}$ & $\mathrm{X}$ & $\mathrm{X}$ & $\mathrm{X}$ & \\
\hline 41 & $5 / 3$ & gray ore type & $\begin{array}{c}\text { main Mn carbonate } \\
\text { ore bed }\end{array}$ & $\mathrm{X}$ & $\mathrm{X}$ & $\mathrm{X}$ & $\mathrm{X}$ & \\
\hline 42 & $5 / 9$ & gray ore type & $\begin{array}{l}\text { main Mn carbonate } \\
\text { ore bed }\end{array}$ & $\mathrm{X}$ & $\mathrm{X}$ & $\mathrm{X}$ & $\mathrm{X}$ & \\
\hline 43 & $5 / 12$ & gray ore type & $\begin{array}{c}\text { main Mn carbonate } \\
\text { ore bed }\end{array}$ & $\mathrm{X}$ & $X$ & $\mathrm{X}$ & $X$ & \\
\hline 44 & $5 / 14$ & gray ore type & $\begin{array}{c}\text { main Mn carbonate } \\
\text { ore bed }\end{array}$ & $\mathrm{X}$ & $X$ & $\mathrm{X}$ & $X$ & \\
\hline 45 & $5 / 15$ & gray ore type & $\begin{array}{c}\text { main Mn carbonate } \\
\text { ore bed }\end{array}$ & $\mathrm{X}$ & $X$ & $\mathrm{X}$ & $\mathrm{X}$ & \\
\hline 46 & $5 / 16$ & $\begin{array}{c}\text { Radiolarian } \\
\text { clayey marlstone }\end{array}$ & $\begin{array}{l}\text { radiolarian clayey } \\
\text { marlstone (Bs2) }\end{array}$ & $\mathrm{X}$ & $\mathrm{X}$ & $\mathrm{X}$ & $\mathrm{X}$ & $\begin{array}{c}\text { Polgári et al. } \\
\text { (2016ab) }\end{array}$ \\
\hline 47 & $5 / 17$ & $\begin{array}{c}\text { Radiolarian } \\
\text { clayey marlstone }\end{array}$ & $\begin{array}{c}\text { radiolarian clayey } \\
\text { marlstone (Bs2) }\end{array}$ & $\mathrm{X}$ & $\mathrm{X}$ & $\mathrm{X}$ & $\mathrm{X}$ & $\downarrow$ \\
\hline 48 & $5 / 18$ & $\begin{array}{c}\text { Radiolarian } \\
\text { clayey marlstone }\end{array}$ & $\begin{array}{c}\text { radiolarian clayey } \\
\text { marlstone (Bs2) }\end{array}$ & $\mathrm{X}$ & $X$ & $\mathrm{X}$ & $\mathrm{X}$ & \\
\hline 49 & $5 / 19$ & $\begin{array}{c}\text { Radiolarian } \\
\text { clayey marlstone }\end{array}$ & $\begin{array}{c}\text { radiolarian clayey } \\
\text { marlstone (Bs2) }\end{array}$ & $\mathrm{X}$ & $\mathrm{X}$ & $\mathrm{X}$ & $\mathrm{X}$ & \\
\hline 50 & $\mathrm{Z} / 6$ & Mn carbonate & bed No. 2 & $\mathrm{X}$ & $\mathrm{X}$ & & $\mathrm{X}$ & $\begin{array}{c}\text { Polgári et al., } \\
\text { (2012a) }\end{array}$ \\
\hline 51 & $\mathrm{Z} / 7$ & Mn carbonate & bed No. 2 & $\mathrm{X}$ & $\mathrm{X}$ & & $\mathrm{X}$ & $\downarrow$ \\
\hline 52 & $\mathrm{Z} / \mathbf{1}$ & $\begin{array}{c}\text { Radiolarian } \\
\text { clayey marlstone }\end{array}$ & $\begin{array}{l}\text { radiolarian clayey } \\
\text { marlstone (Bs3-4) }\end{array}$ & $\mathrm{X}$ & $\mathrm{X}$ & $\mathrm{X}$ & $\mathrm{X}$ & $\begin{array}{c}\text { Polgári et al., } \\
\text { (2016ab) }\end{array}$ \\
\hline 53 & $\mathrm{Z} / 2$ & $\begin{array}{c}\text { Radiolarian } \\
\text { clayey marlstone }\end{array}$ & $\begin{array}{l}\text { radiolarian clayey } \\
\text { marlstone (Bs3-4) }\end{array}$ & $\mathrm{X}$ & $\mathrm{X}$ & $\mathrm{X}$ & $\mathrm{X}$ & $\downarrow$ \\
\hline 54 & $23 /$ & $\begin{array}{c}\text { Goethite and } \\
\text { celadonite- } \\
\text { bearing chert }\end{array}$ & $\begin{array}{l}\text { overlying chert } \\
\text { ironstone }\end{array}$ & $\mathrm{X}$ & $\mathrm{X}$ & & $\mathrm{X}$ & $\begin{array}{l}\text { Polgári et al. } \\
\text { (2010) }\end{array}$ \\
\hline
\end{tabular}

Legend: *: investigation of samples are from references; Bs1- Radiolarian clayey marlstone below the main ore bed; Bs2- Radiolarian clayey marlstone between the main ore bed and bed No. 2; Bs3-4- Radiolarian clayey marlstone overlying bed No. 2. For details see Figure 2. $\downarrow$ 
A - rock microscopy; B - X-ray powder diffraction (XRD); C - Raman spectroscopy; D - Mass spectrometry (MS); E Gas - chromatography mass spectroscopy (GC-MS); F - Fourier transform infrared spectroscopy (FTIR), O-recent study, sample number by italic letters; G - Chemical analysis (ICP, XRF, MP-AES)

List of minerals: rhodochrosite $\left(\mathrm{MnCO}_{3}\right)$; goethite $(\mathrm{FeOOH})$; celadonite $\left.\left(\mathrm{K}\left(\mathrm{Mg}, \mathrm{Fe}^{2+}\right) \mathrm{Fe}^{3+}\left(\mathrm{Si}_{4} \mathrm{O}_{10}\right)(\mathrm{OH})\right)_{2}\right)$; quartz $(\mathrm{SiO} 2)$ The archive samples can be found at the storage of Institute for Geological and Geochemical Research, HAS.

shale, brownish, Fe-rich woven texture and filamentous forms were observed, as mineralized microbially produced sedimentary structures (MMPSS, Polgári et al., 2012ab; Fig. 3). With higher magnification, complex, pearl-necklace-like filamentous structures were observed, which resembled fossilized bacterial forms. Sometimes the Mn-rich parts had brighter bands, but it usually appeared on the contact zone of the ore and the footwall.

The clay mineral rich samples have heterogenous mineral content, the Mn oxide-bearing parts occur with biodebris, and the greenish clay minerals usually appear in patches. In these samples, elongated brownish, Ferich lines and bands were characteristic (average thickness are 0.1-0.2 mm). It has the same tiny filamentous textural elements like the Mn oxide parts, but without oxidized Mn mineral forms and lower average quantity of Fe oxides. All of the ore parts have low biodebris content (mainly Echinozoa fragments). As a whole, the Mn deposit contains a series of Fe-rich biomats of micrometer scale, and at some places also macroscopic evidences of microbial contribution in the form of stromatolites can be seen (stromatolite is a geological structure from micrometer to some meters scale made by microbial contribution). Previous studies proved the Fe oxihydroxide (goethite-FeOOH) content of the filamentous forms as mineralized microbially produced sedimentary structures (MMPSS, Polgári et al., 2012b).

By the FTIR, the different Fe-oxide minerals such as goethite (wave number: $877 \mathrm{~cm}^{-1}$ ), maghemite (wave number: $607 \mathrm{~cm}^{-1}$ and $697 \mathrm{~cm}^{-1}$ ) and ferrihydrite (wave number: $602 \mathrm{~cm}^{-1}$ ) were characterized (Table 2). Beside these, clay minerals (wave number $990 \mathrm{~cm}^{-1}$ ) were also identified, but this method cannot be useful for the identification of different Mn oxides and the prompt characterization of clay minerals, so former studies were also taken into consideration (e.g. Polgári et al., 2012ab; 2013, 2016ab), which found manganite, pyrolusite, vernadite, Ba- and K-rich Mn minerals. The organic matter content shows selective enrichment with the band-like Fe-rich zones, but the quantitative measurements were not possible because of the superponation of the peaks which belong to the organic and inorganic matter. The organic matter content of the Fe-rich zones is diverse, C-C (wave number: $1602 \mathrm{~cm}^{-}$ ${ }^{1}$ ), C-O (wave number: $1155 \mathrm{~cm}^{-1}$ ) and C-H single and double bonds (wave number: $2852 \mathrm{~cm}^{-1}$ and $2926 \mathrm{~cm}^{-}$ ${ }^{1}$ ) were identified. At two areas aromatic groups (wave number: $3090 \mathrm{~cm}^{-1}$ ) were also detected.

Based on these results it can be assumed that series of fossilized biomats were identified, all of the micro- and macrotextural features support this scenario (filamentous, pearl-necklace-like forms and bandedlike occurrences of different mineral phases, stromatolite-like appearance) with the mineralogical (different Fe- and $\mathrm{Mn}$-minerals, with high ratio of poorly ordered phases) and geochemical (selective enrichment of the different types of organic matter with the Fe-, Mn-rich mineral phases) data support this. Concerning recent results, which focused to the initial phase of the manganese mineralization, series of similar Fe-biomat-like forms were detected which are common in the different types of the main $\mathrm{Mn}$ carbonate ore bed (Polgári et al., 2012ab).

As Vigh et al. (2013) showed, the U and Th concentration was enriched in the black shale parts of the ore deposit, so we assume that in that part of the ore the biological effects were weaker than the

geochemical properties (e.g. reductive environment is needed to the immobilization of the $U$ cations). While in the initial oxide ore, there was indication that $\mathrm{K}$ was enriched in the clay minerals, causing higher radiation via the decay of the ${ }^{40} \mathrm{~K}$ isotope, the $\mathrm{Rn}$ could appear in the oxide parts too, by the former cellular activity, which enriched the Ra content by the material of the bacterial metabolism (e.g. like co-fluctuation). The determination of distribution of $\mathrm{Ra}$ content in the profile needs further investigation.

As the natural radionuclides content of the footwall limemarlstone is low, and on the other hand the initial part of Mn mineralization also contains series of biomats (Molnár, 2015; Molnár et al., 2017 and recent study), the role of high reactive surface of the poorly crystallized Fe- Mn oxides and the absorption capacity of clay minerals also could be important.

\section{CONCLUSION}

In this study it was shown that former biological activity could form diverse mineral association with extensive areal occurrence and microbial activity could result ores with great economic importance. The biologically (microbially) mediated ore formation is a complex process, the role of microbes needs complex investigation from macro to micro scales, including the inorganic and organic compounds. 

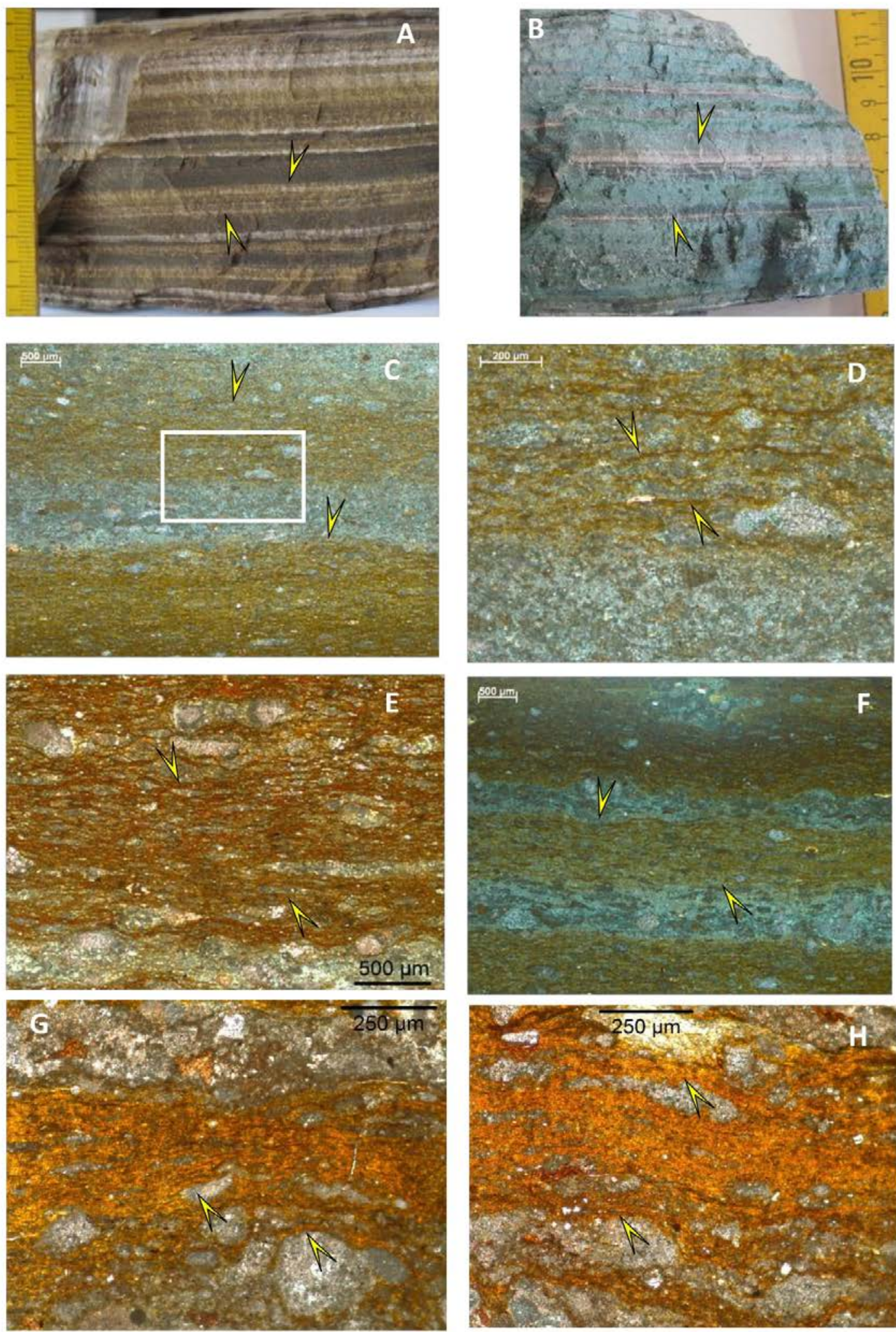

Figure 3. Representative fine-laminated Mn carbonate ore samples (cut surfaces) (A-B) and microtexture. (A) Brown Mn carbonate ore, sample No. 3/8; (B) Green Mn carbonate ore, sample No. 1/13; (C-H) Series of Fe-rich biomats in the main Mn carbonate ore, representative images (arrows). (C) Sample No. 4/19; (D) Enlarged part of signed area (C); (E) Sample No. 4/20; (F) Sample No. 4/23; (G-H) Sample No. 4/7. (The matrix is Ca-rhodochrosite, celadonite and smectite, Jurassic age (196 My), Úrkút, Bakony Mts., Hungary. (C-H) optical rock microscopy, transmitted light, 1 Nicol; Photos by A. Müller and M. Polgári) 
Table 2. Mineral phase and organic material composition and frequency of phases in FTIR spectra

\begin{tabular}{|c|c|c|c|c|c|c|c|c|c|}
\hline \multirow[t]{2}{*}{ Mineral phase } & \multirow[t]{2}{*}{ References } & \multirow{2}{*}{$\begin{array}{l}\text { Wavelength } \\
{\left[\mathrm{cm}^{-1}\right]}\end{array}$} & \multicolumn{7}{|c|}{ Sample ID* } \\
\hline & & & 1/1/A & 1/1/B & 1/1/C & 1/1/D & 2/1/A & 2/1/B & $2 / 4 / C$ \\
\hline & & $\begin{array}{l}\text { Total No. of } \\
\text { spectra } \rightarrow\end{array}$ & 1 & 3 & 5 & 2 & 2 & 4 & 4 \\
\hline ferrihydrite & Glotch \& Rossman 2009 & 604 & 0 & 0 & $2 / 5$ & $2 / 2$ & $1 / 2$ & $2 / 4$ & $2 / 4$ \\
\hline maghemite & Glotch \& Rossman 2009 & 607,637 & 0 & $1 / 3$ & $2 / 5$ & 0 & 0 & $1 / 4$ & $1 / 4$ \\
\hline akaganeite & Glotch \& Rossman 2009 & 663,787 & 0 & $1 / 3$ & $4 / 5$ & $2 / 2$ & 0 & $1 / 4$ & 0 \\
\hline rhodochrosite & Müller et al., 2014 & 712,864, & $1 / 1$ & $3 / 3$ & $2 / 5$ & 0 & $1 / 2$ & $2 / 4$ & $2 / 4$ \\
\hline Si-O stretching of quartz & Madejová \& Komádel, 2001 & 776 & 0 & 0 & 0 & 0 & $1 / 2$ & 0 & $2 / 4$ \\
\hline goethite & Glotch \& Rossman 2009 & 877 & 0 & $1 / 3$ & $3 / 5$ & $2 / 2$ & 0 & 0 & 0 \\
\hline chlorite & Udvardi et al., 2014 & 980 & 0 & $1 / 3$ & $3 / 5$ & & $1 / 2$ & $1 / 4$ & $1 / 4$ \\
\hline $\begin{array}{l}\text { clay } \\
\text { (kaolinite/montmorillonite) }\end{array}$ & $\begin{array}{l}\text { Madejová \& Komádel, } \\
\text { 2001; Madejová, } 2003\end{array}$ & $989,1000,3570$ & 0 & $1 / 3$ & $3 / 5$ & $2 / 2$ & $2 / 2$ & $1 / 4$ & 0 \\
\hline apatite & $\begin{array}{l}\text { Figuerido et al., 2012; } \\
\text { Beasley et al., 2014; } \\
\text { Veiderma et al., 1998 }\end{array}$ & 793, 1012-1031 & 0 & 0 & $2 / 5$ & 0 & 0 & $1 / 4$ & $2 / 4$ \\
\hline \multicolumn{10}{|l|}{ Organic compounds } \\
\hline v s C-O-C, C-C & Parikh \& Chorover, 2006 & 1078 & 0 & 0 & $1 / 5$ & 0 & 0 & $1 / 4$ & $1 / 4$ \\
\hline v C-O & Parikh \& Chorover, 2006 & 1170 & 0 & 0 & 0 & 0 & $1 / 2$ & $1 / 4$ & $1 / 4$ \\
\hline vs $\mathrm{CO}$ & Parikh \& Chorover, 2006 & $1360-1450$ & 0 & 0 & 0 & 0 & 0 & $1 / 4$ & 0 \\
\hline $\mathrm{d}$ CH2 & Parikh \& Chorover, 2006 & $1454-1482$ & 0 & 0 & $2 / 5$ & $2 / 2$ & 0 & $3 / 4$ & $2 / 4$ \\
\hline $\begin{array}{l}\text { C-N, CH deformation in } \\
\text { PAHs }\end{array}$ & Parikh \& Chorover, 2006 & 1526 & 0 & 0 & $1 / 5$ & $1 / 2$ & 0 & 0 & 0 \\
\hline C-N N-H amide II in PAHs & Parikh \& Chorover, 2006 & $1540-1550$ & 0 & 0 & $1 / 5$ & 0 & 0 & $3 / 4$ & 0 \\
\hline $\mathrm{C}=\mathrm{C}$ asym. stretch & Parikh \& Chorover, 2006 & 1598 & $1 / 1$ & 0 & 0 & 0 & $1 / 2$ & $3 / 4$ & $1 / 4$ \\
\hline $\begin{array}{l}\text { amide I C=O, C-N, N_H in } \\
\text { PAHs }\end{array}$ & Parikh \& Chorover, 2006 & $1632-1652$ & 0 & $1 / 3$ & $4 / 5$ & $2 / 2$ & 0 & 0 & $1 / 4$ \\
\hline $\mathrm{v}$ as $\mathrm{COOH}$ & Parikh \& Chorover, 2006 & $1720-29$ & $1 / 1$ & 0 & $1 / 5$ & $2 / 2$ & 0 & $1 / 4$ & 0 \\
\hline $\mathrm{C}=\mathrm{O}$ & Parikh \& Chorover, 2006 & 1799 & 0 & $1 / 3$ & $1 / 5$ & $1 / 2$ & 0 & 0 & 0 \\
\hline $\mathrm{C}=\mathrm{O}$ & Müller et al., 2014 & 2343 & $1 / 1$ & 0 & 0 & 0 & 0 & 0 & 0 \\
\hline $\mathrm{C}=\mathrm{O}$ & Müller et al., 2014 & 2365 & $1 / 1$ & 0 & 0 & 0 & 0 & 0 & 0 \\
\hline $\begin{array}{l}\text { C-H sym. stretch } \mathrm{CH} 2 \\
\text { (long chain } \mathrm{CH}\end{array}$ & Parikh \& Chorover, 2006 & 2853 & $1 / 1$ & $1 / 3$ & $4 / 5$ & $2 / 2$ & $1 / 2$ & $3 / 4$ & $2 / 4$ \\
\hline $\begin{array}{l}\text { C-H asym. Stretch } \mathrm{CH} 2 \\
\text { (long chain } \mathrm{CH} \text { ) }\end{array}$ & Parikh \& Chorover, 2006 & 2926 & $1 / 1$ & $1 / 3$ & $4 / 5$ & $2 / 2$ & $1 / 2$ & $3 / 4$ & $2 / 4$ \\
\hline combination band of NH4 & Madejová \& Komádel, 2001 & 3047 & 0 & 0 & 0 & $2 / 2$ & 0 & 0 & $2 / 4$ \\
\hline $\begin{array}{l}\text { C-H stretch aromatic ring } \\
\text { (long chain } \mathrm{CH} \text { ) }\end{array}$ & Parikh \& Chorover, 2006 & 3090 & 0 & $1 / 3$ & $3 / 5$ & 0 & 0 & 0 & 0 \\
\hline
\end{tabular}

*For details see Table 1.

The new genetic model of the Úrkút Manganese Ore Deposit supports this purpose, offering a frame for the case study of high refinement investigations. The microbially mediated mineralization provided an ideal situation for the cation sequestration (high reactive surface of the poorly ordered mineral phases), among them ions of radioactive elements together with the organic matter. Some metabolic activity could induce the enrichment of some chemical compounds with high radioactive radiation (e.g. the bacterial cofluctuation of Ra isotopes). Macro- and microtextural features and the mineral composition supports this scenario. In the case of high cation capacity, and the large amount of ore material produced by microbially mediated mineralization, the mineral procession and mining activity must be made with caution, because of the possibility of health risk of the potentially high ratio of radioactivity.

\section{ACKNOWLEDGEMENTS}

The authors thank the support of National Research, Development and Innovation Office, National Scientific Research Found No. 125060. We appreciate the 
constructive contribution of Zsombor Molnár, technical assistance and photos of Alexandra Müller (IGGR, RCAES HAS, Budapest, Hungary). We thank the careful reviews and constructive suggestions provided by the anonymous reviewers, and editorial handling.

\section{REFERENCES}

Abel-Ghany, H.A., 2010. Natural activities of 238-U, 232Th, 40-K in Manganese Ore. American Journal of Environmental Sciences, 6, 88-92.

Beasley, M.M., Bartelink, Eric J., Taylor, L. \& Miller, R., 2014. Comparison of transmission FTIR, ATR, and DRIFT spectra: implications of assesment of bone bioapatite diagenesis. Journal of Archeological Science, 46, 16-22.

Figueiredo, M.M., Martins, A.G. \& Gamelas, J.A.F., 2012. Characterization of bone and bone-based graft materials using FTIR spectroscopy. INTECH Open Access Publisher.

Fujisawa, A. \& Tazaki, K., 2003. The radioactive microbial mats - In case of Misasa hot springs in Tottori Prefecture. In: Katama N. (ed.): Proceedings: International Symposium of the Kanazawa University $21^{\text {st }}$-Century COE Program Vol. 1., Kanazawa University, Kanazawa, Japan, 328-331.

Glotch, T.D. \& Rossman, G.R., 2009. Mid-infrared reflectance spectra and optical constants of six iron oxide/oxyhydroxide phases. Icarus, 204, 663-671.

Grasselly, Gy. \& Pantó, Gy., 1988. Rare Earth Elements int he Manganese Ore deposit of Úrkút (Bakony Mountains, Hungary). Ore Geology Reviews, 4, 11524.

Kávási, N., Németh, Cs., Kovács, T., Tokonami, S., Jobbágy, V., Várhegyi, A., Gorjánácz, Z., Vigh, T. \& Somlai, J., 2007. Radon and thoron parallel measurements in Hungary. Radiation Protection Dosimetry, 123, 250-3.

Kávási, N., Somlai, J., Vigh, T., Tokonami S., Ishikawa, T., Sorimachi, A. \& Kovács, T., 2009. Difficulties in the dose estimate of workers originated from radon and radon progeny in a manganese-mine. Radiation Measurements, 44, 300-5.

Konhauser, K.O., 2007. Intoduction to geomicrobiology, Blackwell publish, 43-67.

Krumbein, W.E., Ulrike, B., Gorbushina, A.A., Levit, G. \& Palinkska, K.A., 2003. Biofilm, Biodictyon and Biomat - Biolaminites, Oolites, Stromatolites - In: Geophysiology, Global Mechanism and Parahistology, in Fossil and Recent Biofilms (edited by Krumbein W. E., Patterson, D., Zavarzin, G. A.), Springer Science Media, Dordrecht, 1-29.

Madejová, J. \& Komadel, P., 2001. Baseline studies of the clay minerals society source clays: infrared methods. Clays and Clay Minerals, 49, 410-432.

Madejová, J., 2003. FTIR techniques in clay mineral studies. Vibrational spectroscopy, 31/1, 1-10.

Molnár, Zs., 2015. Initial Fe-Mn-oxide ore indications in the footwall of the Toarcian Úrkút Mn-carbonate ore deposit, Hungary. Thesis. Eötvös University,
Budapest, 208 p.

Molnár, Zs., Polgári, M., Hein, J.R., Józsa, S., Fekete, J., Gyollai, I., Fintor, K., Bíró, L., Szabó, M., Rapi, S., Forgó, P. \& Vigh T., 2017. Fe-Mn oxide indications in the feeder and mound zone of the Jurassic Mncarbonate ore deposit, Úrkút, Hungary. Ore Geology Reviews, 86, 839-855.

Müller, C.M., Pejcic, B., Esteban, L., Delle Piane, C., Raven, M. \& Mizaikoff, B., 2014. Infrared Attenuated Total Reflectance Spectroscopy: An Innovative Strategy for Analyzing Mineral Components in Energy Relevant Systems. Scientific Reports 4.

Parikh, S.J. \& Chorover, J., 2006. ATR-FTIR spectroscopy reveals bond formation during bacterial adhesion to iron oxide. Langmuir, 22/20, 8492-8500.

Polgári, M., Hein, J.R., Bíró, L., Gyollai, I., Németh, T., Sajgó, Cs., Fekete, J., Schwark, L., Pál-Molnár, E., Hámor-Vidó, M. \& Vigh, T., 2016a. Mineral and chemostratigraphy of a Toarcian black shale hosting Mn-carbonate microbialites (Úrkút, Hungary). Palaeogeography, Palaeoclimatology, Palaeoecology, 459, 99-120.

Polgári, M., Hein, J.R., Fórizs, I., Vigh, T., SzabóDrubina, M., Bíró, L., Müller, A. \& Tóth, A.L., 2012a. Microbial processes and the origin of the Úrkút manganese deposit, Hungary. Ore Geology Reviews, Special Issue "Manganese Metallogenesis" 47, 87109.

Polgári, M., Hein, J.R., Németh, T., Pál-Molnár, E. \& Vigh, T., 2013. Celadonite and smectite formation in the Úrkút Mn-carbonate ore deposit (Hungary). Sedimentary Geology, 294, 157-163.

Polgári, M., Hein, J.R., Tóth, A.L., Pál-Molnár, E., Vigh, T., Bíró, L. \& Fintor, K., 2012b. Microbial action formed Jurassic Mn-carbonate ore deposit in only a few hundred years (Úrkút, Hungary). Geology, 40(10), 903-906.

Polgári, M., Hein, J.R., Tóth, M., Brukner-Wein, A., Vigh, T., Bíró, L. \& Cserháti, C., 2010. Lias manganese deposits, Hungary Genesis of a regionally widespread celadonitic chert ironstone bed overlying Upper Lias manganese deposits, Hungary. Journal of the Geological Society London, 167, 313-328.

Polgári, M., Németh, T., Pál-Molnár, E., Futó, I., Vigh, T. \& Mojzsis, J.S., 2016b. Correlated chemostratigraphy of Mn-carbonate microbialites (Úrkút, Hungary). Gondwana Research, 29, 1, 278289.

Polgári, M., Szabó, Z. \& Vigh, T., 2017. Manganese ore mining at Úrkút (1917-2017), GeoLitera Publishing House, Szeged, 260p. (ISBN 978-963-306-547-1).

RUFF Database

Tazaki, K., 1999. Architecture of biomats reveals history of geo-, aqua-, and bio-systems. Episodes, 22(1), 22 23.

Tazaki, K., 2009. Observation of microbial mats in radioactive hot springs. Science Reports of Kanazawa University 53, 25-37.

Tsezos, M., Baird, I.H. \& Shelmit L.W., 1987. Elution of 
Radium adsorbed by microbial mats. Chemical Engineering Journal, 34, B57-B64

Udvardi, B., Kovács, I. J., Kónya, P., Földvári, M., Füri, J., Budai, F., Falus, Gy., Fancsik T., Szabó Cs., Szalai Z. \& Mihály, J., 2014. Application of attenuated total reflectance Fourier transform infrared spectroscopy in the mineralogical study of a landslide area, Hungary. Sedimentary Geology, 313, 1-14.

Veiderma, M.I.H.K.E.L., Knubovets, R.E.N.A. \&
Tonsuaadu, K., 1998. Structural properties of apatites from Finland studied by FTIR spectroscopy. Bulletin Geological Society of Finland, 70, 69-75.

Vigh, T., Kovács, T., Somolai, J., Kávási, N., Polgári, M. \& Bíró, L., 2013. Terrestrial radioisotopes in black shale hosted Mn-carbonate deposit (Úrkút, Hungary). Acta Geophysica, 61(4), 831-847

Wiener, S., Dove, P.M. \& De Yoreo, J.J., 2003. Biomineralization, Reviews of Mineralogy and Geochemistry, 54, 15-113.

Received at: 30. 01. 2018

Revised at: 19. 02. 2018

Accepted for publication at: 18. 03. 2018

Published online at: 22. 03. 2018 